\title{
MARKET ORIENTATION
}

\subsection{Introduction}

The 1514 Informacie, an assessment of the economic situation of the towns and villages of Holland for taxation purposes, paints a vivid picture of the way villagers in early 16th-century Holland made a living. In Ouddorp in West-Friesland, for instance, some villagers cultivated the land, others hired themselves out with their carts as carriers, and five or six were employed as sailors on a herring buss. In Aalsmeer, just south of Amsterdam, the population was engaged in peat digging, but they also held cows and cut reeds. In Zwammerdam, north of Gouda, the villagers likewise held cows and cultivated the land; in addition, the women were engaged in spinning wool and the men mostly in digging. The people of Streefkerk, east of Rotterdam, held cows and grew hemp and some oats; they were, moreover, engaged in fishing and catching birds, and in digging and diking. ${ }^{1}$ The variety of activities is striking; furthermore, by their nature the majority of these activities must have involved the production of goods (or services) for the market.

Even though a growing body of research stresses the importance of markets-both commodity markets and factor markets-for medieval economies, the timing and the extent of commercialisation are still subjects of debate. This is partly due to difficulties with measuring the level of commercialisation: good data are difficult to find. Urbanisation is an important element: towns could not exist without markets to provide them with foodstuffs and raw materials. Conversely, a large part of the urban population was engaged in producing commodities for, or providing services through, the market. Nevertheless, the importance of self-provisioning among townsmen should not be underestimated. For artisanal products and services, auto-consumption cannot have taken up more than a very small part of total production; but for agriculture it was another matter. Many townspeople grew part of

${ }^{1}$ Fruin, Informacie, 58, 135, 312, 551. 
their own food. Early 14th-century tax registers for the English town of Colchester, for instance, show that approximately half of all households owned substantial grain stocks or livestock. Among them were several well-to-do landowning artisans and merchants, but even townspeople of middling wealth frequently held one or more pigs or cows. Although they probably intended to sell part of the produceotherwise, the beasts would not have been included in the tax register-they no doubt used some of it to supply their own households. In fact, greater self-sufficiency was probably one of the reasons why urban craftsmen and traders held on to landownership. ${ }^{2}$

More importantly, urban population numbers alone are not sufficient to establish the level of commercialisation: the rural population also engaged in commercial activities, either in the shape of proto-industrial production and services, or through market-oriented agricultural production. The idea that peasants were by nature subsistence-oriented and only turned to the market if they were forced to, has proved incorrect. ${ }^{3}$ The production of foodstuffs and raw materials for the market was an integral part of peasant agriculture. However, the neo-classical alternative-of peasants always ready and even eager to engage in specialisation and market-oriented production-is also unsatisfactory. It does not explain why in some situations peasant reacted to market opportunities with great alacrity, whereas at other times and in other places they were much more reluctant to do so. Institutional economics offer a fruitful approach to this paradox, by predicting that peasants respond to the institutional framework that shapes the functioning of markets. If market institutions are efficient and transaction costs are low, peasants will be stimulated to produce for the market; if, on the other hand, markets are difficult to enter or unsafe, posing high barriers to trade, peasants may prefer subsistence as the less costly or less risky alternative. ${ }^{4}$ It is from this point of view that an attempt is made here to compare the pace and timing of the process of commercialisation in Holland with the situation in Flanders and England. If neo-institutionalist theory is correct, the different

2 Britnell, 'Specialization of Work', 11-13.

3 The assumption goes back to the work of the Russian economist, Chayanov (Chayanov, Theory of Peasant Economy), but also features in the work of Robert Brenner, e.g. 'Agrarian Roots', 236. For the involvement of peasants in market exchange, cf. Masschaele, Peasants, Merchants, and Markets, 33-56.

${ }^{4}$ Hoppenbrouwers and Van Zanden, 'Restyling the Transition', 22-26; Epstein, 'Cities, Regions and the Late Medieval Crisis', 5-8. 
institutional frameworks for commodity markets in the three countries should result in different levels of market orientation.

This hypothesis will be tested by estimating the share of labour input devoted to providing goods or services for the market. In a study focusing on commodity markets, this may seem a rather roundabout way to get to the heart of the issue, but alternatives all break down in the face of data problems. The total volume of market transactions cannot, at least for Holland, be calculated with any degree of accuracy before the early 16th century: sources that would allow for such a calculation are simply unavailable. Directly estimating the share of goods produced for the market is difficult because of the very frequent occurrence of consecutive stages of production. The only way to deal with this would be through a calculation of added value for each stage, but again the source material poses restrictions. An approach via labour input avoids most of these problems, while it is also in keeping with the theoretical starting point outlined above. An additional advantage is that it allows us to use the results of studies on occupational structure and specialisation of labour in the three countries. It should be clear that the estimates indicate orders of magnitude, and no more than that.

We will look at three elements: the level of urbanisation (with a correction for self-provisioning agrarian activities of townspeople), nonagricultural activities in the countryside, and the market orientation of rural agrarian production. For each element, an attempt is made to arrive at a quantitative estimate of the labour input for two dates: the beginning or middle of the 14th century, and the end of the 15 th or beginning of the 16th century. Together, the estimates for the three elements provide an indication of the total proportion of labour input devoted to market-oriented production at those two moments in time. Considering the timeframe covered by this book, assessments for the early 13 th century and the middle of the 15 th century would have been more logical. However, for Holland, but to a lesser extent also for Flanders and England, early 13th-century data simply do not allow for quantification. Moreover, for all three regions, detailed information in the form of fiscal documents is available for the late 15 th or early 16 th century, providing a much needed reliable point of reference for many estimates.

Neither Holland nor Flanders or England were perfectly homogeneous regions, but the degree of heterogeneity differed. In addition, there is the more practical issue of differences in the availability of data. In combination, these two facts call for a differentiated approach. 
Holland was the smallest region and although there were internal differences-urbanisation for instance was lower in the north than in the centre or south of the county-for an analysis of market orientation it is still possible to discuss Holland as one region. In Flanders, on the other hand, agriculture in the coastal region-with its predominance of large leasehold farms that mainly produced for the market-was radically different from the system of peasant smallholding that prevailed in the rest of county. In order to do justice to this difference, the estimates of market orientation of agriculture and of non-agricultural rural activities in inland Flanders are complemented by separate estimates for the situation in coastal Flanders. Finally, England was of course many times larger than Holland or Flanders and more heterogeneous than either. However, accurate data needed to make calculations for specific regions are largely lacking; in fact, even in aggregated form the English data display several uncertainties. Therefore, for England all figures are presented as ranges. In addition, an attempt is made to establish where, with respect to the indicated ranges, the most urbanised and most densely populated eastern part of Englandexemplified by the county of Suffolk-should be positioned.

It cannot be stressed sufficiently that no more than an indication of the order of magnitude is intended. Indeed, the data do not permit anything else; estimates, and sometimes rather rough ones at that, are all that is to be had. When estimates for different aspects are combined in an aggregate figure, distortions are moreover easily magnified. Nevertheless, while figures for Holland, Flanders and England separately are open to discussion, by carefully comparing the information available for the three regions it is possible to provide an impression of the differences in long-term developments. Linking these differences to the institutional framework is more difficult. As was shown earlier, other factors besides institutions may also affect market performance. For Holland, ecological problems reducing possibilities for bread grain cultivation and the growing demand from the urban middle classes for products like dairy, meat, and fresh sea-fish have earlier been identified as important elements; they will feature again in this chapter.

Two aspects of methodology need to be clarified in advance. First, in estimating the share of agrarian labour devoted to market-oriented production, the cultivation of fodder and raw materials to be processed by the farmer himself has been assessed according to the destination of the finished product. The labour needed to cultivate the flax used for linen production by the farmer and his family, for instance, has been 
classed as market-oriented, since the linen was ultimately marketed. The second aspect regards the concept 'labour input'. The analysis will be restricted to labour aimed directly at bringing in cash or commodities-in other words, limited to 'professional' activities. Apart from domestic work, this also omits all kinds of unpaid services to members of the local community, such as helping out neighbours at harvest time. Of course, this kind of labour had an economic value, but a lack of data and the difficulties of distinguishing between economic and social activities put quantification out of reach. However, as the restriction to professional activities applies to Flanders and England as well as to Holland, the comparison will probably not be much affected.

\subsection{Holland}

Although in the early 13 th century Dordrecht was already a modestsized river trade centre, and places like Leiden, Delft, Haarlem and Alkmaar were beginning to show the first signs of urbanisation, Holland was still mainly an agrarian region on the margins of European civilisation. Yet, even then the beginnings of a monetary economy must have been in place, in the countryside as well as in the nascent towns. The reclamation of Holland's peat lands provided the colonists with the means to feed themselves and their families. The original standard size of a peatland farm was 16.5 to 18 morgen (around 15 hectares), ${ }^{5}$ and at that time grain cultivation would not have been a problem. Still, taxes and fines would have had to be paid in cash. The first references to payments of schot or jaarbede (a tax to be paid by every household, most likely originating in the dues owed to the count as the owner of all land) date from the early 12th century. Even older (probably late 11th century) is the botting, a monetary compensation replacing the duty to house and feed the count (or his representative) when he visited once every three or four years to preside over the sessions of the supreme court. ${ }^{6}$ If peasants were able to pay taxes in cash, they must have sold at least part of their produce. That they did indeed seek out markets is, moreover, in keeping with the evidence presented

\footnotetext{
5 Van der Linden, Cope, 26-36.

6 Bos-Rops, Graven op zoek naar geld, 24; and Gosses, Welgeborenen en huislieden, 17-18; OHZ I, no. 238 (schot/jaarbede); Blok, 'Holland sinds Gosses', 18-25; Gosses, De vorming van het graafschap Holland, 67-68; Fockema Andreae, 'Bottinge'; and Allan, Kennemer landrecht, 196-199 (botting).
} 
in Chapter 2 on the existence of 12th-century fairs or markets in the earliest administrative and religious centres of Holland, and of an important cattle trade between the southern part of Holland and the towns of Flanders and Brabant around the year 1200.

In the late 13th century, the existing towns began to expand and several new ones emerged. Nevertheless, by 1300 only about 30,000 people (14\% of the total population) lived in towns. Most of these towns were small or very small; even Dordrecht had no more than around 5,000 inhabitants in $1300 .^{7}$ By 1514 , when the Informacie renders the first reliable general assessment of economic and demographic conditions in the towns and villages of Holland, the situation had changed drastically. The urban population had grown to about 124,000, resulting in an urban ratio of $45 \%$. In the southern half of Holland, the ratio was even considerably higher. ${ }^{8}$ To contemporaries this must have been an incredibly high percentage: it surpassed urbanisation levels in Flanders and northern Italy. One thing had remained unchanged, however: the size of individual towns was still modest. That even at this stage $40 \%$ of the urban population was living in towns with 2,000 to 10,000 inhabitants and another $12 \%$ in towns with less than 2,000 inhabitants is perhaps not remarkable: small and very small towns also dominated in many other parts of northwestern Europe. More striking is the fact that large cities (with 20,000 residents or more) were entirely absent: no town had developed that came even remotely near a metropolis. The remaining $48 \%$ of the urban population of Holland lived in one of five medium-sized towns: in Leiden (about 14,000 inhabitants), Amsterdam, Haarlem, Delft, and Dordrecht (each with 11,000 to 12,000 inhabitants). ${ }^{9}$

Developments in the second half of the 14th century are particularly striking. The Black Death probably did not take death tolls of up to 50\% - as in England and Mediterranean France-but losses from the echo epidemics of the 1360 s to 1380 s still appear to have been severe. ${ }^{10}$

7 Visser, 'Dichtheid en bevolking', 19; cf. Van Herwaarden et al., Geschiedenis van Dordrecht, 246, who gives an estimate of 6,000 inhabitants in 1325.

${ }^{8}$ Van Bavel and Van Zanden, 'Jump-Start', 511 and 529. For the difference between the northern and the southern part of Holland, cf. De Vries, Dutch Rural Economy, $86-87$.

9 The distribution of the urban population over very small, small, and mediumsized towns has been constructed from the information on town populations in 1514 given by Lourens and Lucassen, Inwonertallen, 54-71, 100-123.

${ }_{10}$ Blockmans, 'Social and Economic Effects', esp. 861-862. 
However, they were compensated for very quickly: by 1400 the urban population had surpassed its pre-Plague level. Only a considerable migration to the towns could have accounted for this. For Leiden and Gouda, a sizable immigration-mainly from the surrounding countryside-has indeed been demonstrated for the late 14th century. The numbers of registered new burgesses suggest a migration that exceeded, relatively speaking, that to the cities of Flanders in the same period. Besides deteriorating conditions in the Holland central peat district, where arable farming was becoming increasingly difficult, the attractions of the flourishing urban economies probably contributed to this migratory wave. ${ }^{11}$ In the 15 th century, towns continued to expand. Only in the last two decades of the century did economic malaise trigger a decline in towns like Leiden, Gouda, and Haarlem; Amsterdam, however, still experienced some growth. ${ }^{12}$

No doubt the urban population was largely occupied in marketoriented industrial production or in providing services, but the role of agriculture should not be underestimated. It is a telling sign that the urban liberties of the Brabant-Holland family, adopted by a large number of towns in Holland between the mid-13th and the mid-14th century, contain a section stating the right of each burgess to be absent from town for two weeks during summer to bring the harvest in and for another two weeks during autumn to sow next year's crop without jeopardising his burgess status. ${ }^{13}$ Moreover, within the urban freedom, the young towns had many open spaces that provided room for stables, paddocks, vegetable gardens, orchards, and even corn fields. ${ }^{14}$

The 1514 Informacie suggests that in the smallest towns this situation hardly changed. For seven out of the ten towns with less than 2,000 inhabitants for which the Informacie gives information on the occupational structure, arable farming or animal husbandry were recorded; in five towns the local authorities actually mentioned agriculture before all other activities. ${ }^{15}$ The order in which the main

11 De Boer, Graaf en grafiek, 139-166, esp. 144, 164.

12 Van Bavel and Van Zanden, 'Jump-Start', 507 (Leiden); Lourens and Lucassen, Inwonertallen (other towns).

13 For instance Haarlem: $O H Z$ II, no. 672-673, art. 5.

14 Van Herwijnen, 'Stad en land', 20.

15 Fruin, Informacie. The five very small towns that mention agriculture first are Medemblik, Oudewater, 's-Gravenzande, Asperen and Heukelum (104, 263, 350, 599, 601). Muiden and Haastrecht also mention agriculture but rank it lower (201, 392); Beverwijk, Weesp and Woerden do not mention it at all $(17,197,248)$. 
occupations are recorded in the Informacie has been used by Van Zanden for a reconstruction of the structure of labour input in the countryside at the end of the Middle Ages. Assuming that village authorities reported occupational activities in order of importance, he attributes weights to each of these activities accordingly and thus arrives at an estimate of their share in total rural labour input. ${ }^{16}$ We shall return to the results of Van Zanden's calculations for the countryside shortly. Here it is of interest that the data for the smallest towns can be processed in the same way, with one adaptation: more people than in villages would have been engaged in local retailing and a variety of other professions not included in the 'main occupations' mentioned in the Informacie. Depending on the assumptions made on this issue, the share of labour input devoted to agriculture can be calculated at 20 to $35 \% .{ }^{17}$

In the larger towns the role of agriculture was more modest. With growth, much of the urban open space fell victim to the needs of industry and housing for the urban population, which must have been accompanied by an increase in the proportion of urban labour input in market-oriented manufacture and services. For towns with 2,000 to 10,000 inhabitants, a calculation based on the occupational activities mentioned in the Informacie renders a share of less than $10 \%$ of urban labour input devoted to agrarian activities. However, in this category the obvious domination of the industrial and service sectors may easily have given rise to an underestimation of the primary sector. The case of Edam (2,300 inhabitants) illustrates this. For this town, the Informacie mentions only shipbuilding and shipping as main occupations, ${ }^{18}$ but the exceptionally detailed local tax registers display a pattern very similar to that described earlier for Colchester in England. They show that, at the end of the 15th and the beginning of the 16th century, approximately half of all Edam households owned one or more cows, the average being 2.3 animals. In many cases, the head of the household was a sailor, craftsman or trader, with dairying as a

\footnotetext{
16 Van Zanden, 'Taking the Measure', 135.

17 Van Zanden assumes that in small villages $5 \%$ and in large villages $10 \%$ of the population was occupied in retailing and local services. Some very small towns were probably hard to distinguish from large villages, but in Beverwijk or Weesp, where the authorities were unable to mention a main occupation, the number of people engaged in retailing and local services may well have been much larger. I have adopted $10 \%$ as the lower and $50 \%$ as the upper limit.

${ }^{18}$ Fruin, Informacie, 187.
} 
side-employment. ${ }^{19}$ This strongly suggests that for towns with 2,000 to 10,000 residents the proportion of urban labour input devoted to agriculture was not as marginal as the Informacie indicates. A share of 10 to $20 \%$ seems more realistic.

For the five towns with more than 10,000 inhabitants, the Informacie does not mention agriculture at all. Likewise, Van Zanden's reconstruction of the urban occupational structure of Leiden and Dordrecht around 1500, which uses other sources, shows that in these two towns some two-thirds of urban labour input was engaged in the secondary sector and about one third in trade, transport, and other services. The contribution of agriculture was negligible. ${ }^{20}$ However, the data on which Van Zanden based his calculations refer to primary occupation only; agrarian (or in fact any other) side-employment was not recorded. Therefore, the importance of agriculture may again have been underestimated, and a share of up to $10 \%$ seems a reasonable assumption.

Part of the urban agricultural activity was no doubt intended for auto-consumption, but a substantial share of the produce must have been sold on the market. The Edam case again provides an illustration. Even if the members of an Edam household owning cows should each have consumed 4 kilogram of butter and 8 kilogram of cheese per year (this is twice the average consumption for all Hollanders estimated by Van Bavel and Gelderblom and approaches the consumption per head of the well-to-do occupants of Leeuwenhorst Abbey in 1540), autoconsumption would still have been only $40 \%$, leaving the remaining $60 \%$ to be sold. ${ }^{21}$ The share of marketable surplus, however, may have been lower for products of arable farming; therefore, market orientation of urban agricultural activities has been estimated conservatively at $50 \%$. This would result in a share of urban labour devoted to marketoriented activities, non-agrarian and agrarian combined, of 82 to $90 \%$ for the towns with less than 2,000 inhabitants, 90 to $95 \%$ for the towns

19 Boschma-Aarnoudse, Tot verbeteringe, 138-140, 454-455, 470-471. The figure of 2.3 is the unweighted average for $1462(2.4), 1506$ (2.4) and $1514(2.0)$.

${ }^{20}$ Van Zanden, 'Taking the Measure', 136-138. The data have been derived from Unger, 'Economische en sociale structuur', 981-984 (Dordrecht) and Posthumus, Leidsche lakenindustrie I, 400-403 (Leiden).

${ }_{21}$ Assuming, as Van Bavel and Gelderblom do, that 33 litres of milk render 1 kilogram of butter, that 10 litres of milk render 1 kilogram of cheese, and that the annual yield of a cow is 1,000 litres (Van Bavel and Gelderblom, 'Land of Milk and Butter', 59 (note 75). Household size in Edam was 4.62 in 1462 and 3.90 in 1514; here the unweighted average of 4.26 has been used (Boschma-Aarnoudse, Tot verbeteringe, 423-424). 
with 2,000 to 10,000 inhabitants, and 95 to $100 \%$ for the largest towns. The market orientation of the urban sector as a whole can thus be estimated at 88 to $94 \%$ in the middle of the 14th century and 92 to $97 \%$ around 1500; the modest increase is related to the fact that in the meantime many towns had grown in size.

Examples of non-agricultural, market-oriented activities in Holland's late medieval countryside are easy to find. In fact several have already been mentioned, varying from the brewing and spinning that took place in the vicinity of many towns to the manufacturing of a loom in Noordwijkerhout. ${ }^{22}$ For a quantitative assessment of the situation around 1500, Van Zanden's calculations, reflecting the variety of activities mentioned for each village in the Informacie, provide a good point of departure. The results are remarkable: the share of rural input in agriculture was only about $41 \%$, a very low rate from an international perspective. ${ }^{23}$ There is obviously a relationship with the changes rural Holland experienced in the late 14th and early 15th century. The subsidence of the peat soil and the subsequent deterioration of ecological conditions made bread grain cultivation increasingly difficult. In a reaction to the diminishing prospects for subsistence farming, peasants developed a wide range of non-agrarian, market-oriented activities such as peat digging, shipping and fishing, spinning and weaving, and the construction and maintenance of dikes and canals. ${ }^{24}$

By 1500 not just non-agrarian activities in the Holland countryside were market-oriented, but so too were most agrarian activities. This may seem surprising, since this development had not been accompanied, as it was in England, by the rise of large landownership, tenant farming, and wage labour. In Holland, for the time being, peasants held on to their land: the structure of small family farms remained in place until at least the middle of the 16th century. By then, about 20\% of labour input in agriculture was performed as wage labour. ${ }^{25}$ Yet the nature of the produce of the small Holland farms makes it clear that only part of this produce was consumed by the farmer and his family. Meat and dairy, the products of animal husbandry, were primarily designated for urban markets in Holland or abroad. Where arable farming

\footnotetext{
22 See sections 4.3 and 7.5 .

23 Van Zanden, 'Taking the Measure', 134-138.

24 Van Zanden, Rise and Decline 30-34; Van Zanden, 'Third Road', 87-89.

25 Van Bavel, 'Rural Wage Labour', 55-56.
} 
did take place, it produced, besides pulses and vegetables, mainly products that served as raw material for the urban industries: hemp, hops, barley, and oats. ${ }^{26}$

Peasants no doubt ate home-grown peas, beans and vegetables, and could well have drunk home-brewed beer made of their own barley and oats. Even if they brought most of their meat and dairy to the market, they would not have missed the opportunity to consume some of it at home. Nevertheless, a considerable part of rural agrarian labour must have been market-oriented, as is demonstrated by dairy production in the Waterland countryside. Around the year 1500, three quarters of households in the villages around Edam owned cows, the average number being 4.8 head. ${ }^{27}$ Fragmentary evidence from other parts of Holland suggests that this was fairly normal: 5 to 6 head seems to have been the typical size of a peasant's herd. ${ }^{28}$ The marketable surplus the Waterland villagers could expect from a herd of this size can be calculated in the same way as has just been done for urban livestock owners: it was around $80 \% .{ }^{29}$ Again, market orientation may have been less pronounced for products other than dairy-to be on the safe side, market orientation of the agrarian sector as a whole has therefore been estimated at 60 to $80 \%$.

Combined with the figures on urbanisation and on non-agrarian occupations in the countryside, it follows that around the year 1500 between $87 \%$ and $94 \%$ of the total labour input of Holland's population was devoted to the production of commodities and the provisioning of services through the market.

Before the early 16th century, information on Holland's rural occupational structure is more scarce, but Van Bavel's study of early protoindustrialisation provides a starting point. Based on estimates for a large number of different non-agrarian activities-peat-digging, peat transport, fishery, and the cloth and linen industry being the most important ones-Van Bavel estimates that even in the middle of the 14 th century about a quarter of rural labour was not devoted to agriculture. This figure does not include digging and diking, or the labour

\footnotetext{
${ }^{26}$ Bieleman, Geschiedenis van de landbouw, 56-76.

27 Boschma-Aarnoudse, Tot verbeteringe, 474-475. The figure of 4.8 is the unweighted average for 1462 (5.4), 1506 (4.8) and 1514 (4.2).

28 De Vries, Dutch Rural Economy, 70-71.

29 Assuming a household size of 4.6 , based on the unweighted averages of 4.8 in 1462 and 4.35 in 1506 (Boschma-Aarnoudse, Tot verbeteringe, 423-424).
} 
of the many millers, bakers, blacksmiths, and others servicing the local community. For 1500 Van Bavel estimates the share of rural labour input involved in digging and diking at $5 \%$ and the share engaged in local services at $10 \%{ }^{30}$ In the middle of the 14 th century, the figures may have been somewhat lower, although there can be no doubt both groups existed. Egmond Abbey, for instance, frequently bought nails and iron tools from at least two local smiths in the latter part of the 14th century. The Abbey's accounts over 1388 also mention lists of wages paid to labourers hired to dike the Zijpe, a sea-arm that had been causing extensive flooding. ${ }^{31}$ An estimate of around $30 \%$ of total rural labour input in non-agrarian activities in the middle of the 14th century is therefore not presumptuous.

Of the remaining $70 \%$ devoted to agrarian work, a much larger proportion than in the early 16th century would have been devoted to subsistence-oriented activities: before 1350, grain cultivation did not pose any problems and urban demand for provisions was still modest. For the English peasantry of the late 13th and early 14th century, the share of labour that went into growing crops for the market is estimated at 30 to $40 \% .{ }^{32}$ There are no good grounds to argue this proportion was either much higher or much lower in Holland.

Table 7 combines the figures. It shows that by the middle of the 14th century an estimated total of less than two-thirds of Holland's labour input was devoted to market-oriented activities, while in 1500 this share had risen to about $90 \%$. Two conclusions can be drawn. The first is that even a late developer like Holland must have experienced a significant growth of commercialisation before the middle of the 14th century. A reliable estimate for the year 1100 or 1200 cannot be given, but there can be no doubt that at that time market orientation was far below the level of 1348. Secondly, the process of commercialisation continued to proceed rapidly between the middle of the 14th and the end of the 15th century. The development is even more striking when the simultaneous growth of population numbers from around 235,000 in 1348 to about 275,000 in 1500 is taken into account. By the end of the 15th century, the number of people dependent on the market for their sustenance was about $70 \%$ higher than 150 years earlier.

30 Van Bavel, 'Early Proto-Industrialization', 1143.

${ }_{31}$ Hof, Egmondse kloosterrekeningen, 49-59.

32 See below, section 9.4. 
Table 7 Share of labour input in market-oriented activities, Holland

\begin{tabular}{|c|c|c|}
\hline & $\begin{array}{l}\text { Mid 14th } \\
\text { century }\end{array}$ & $\begin{array}{l}\text { Late } 15 \text { th / early } \\
16 \text { th century }\end{array}$ \\
\hline & $\begin{array}{l}\text { Population: } \\
\text { c. } 235,000\end{array}$ & $\begin{array}{l}\text { Population } 1514: \text { c. } 275,000 \\
\text { Density: c. } 60 \text { residents } \\
\text { per } \mathrm{km}^{2}\end{array}$ \\
\hline \multicolumn{3}{|l|}{ Urban sector } \\
\hline $\begin{array}{l}\text { a. Urban population as percentage } \\
\text { of total (see text) }\end{array}$ & $23 \%$ & $45 \%$ \\
\hline $\begin{array}{l}\text { b. Share of urban labour input in } \\
\text { market-oriented activities (see text) }\end{array}$ & $88-94 \%$ & $92-97 \%$ \\
\hline $\begin{array}{l}\text { c. Resulting share of total population } \\
\text { in market-oriented activities }(\mathrm{a} \times \mathrm{b})\end{array}$ & $20-22 \%$ & $41-44 \%$ \\
\hline \multicolumn{3}{|l|}{ Rural sector } \\
\hline $\begin{array}{l}\text { d. Rural population as percentage } \\
\text { of total }(100 \%-a)\end{array}$ & $77 \%$ & $55 \%$ \\
\hline $\begin{array}{l}\text { e. Share of rural labour input in } \\
\text { non-agrarian activities (see text) }\end{array}$ & $30 \%$ & $59 \%$ \\
\hline $\begin{array}{l}\text { f. Resulting share of total population } \\
\text { in market-oriented activities }(\mathrm{d} \times \mathrm{e})\end{array}$ & $23 \%$ & $32 \%$ \\
\hline $\begin{array}{l}\text { g. Share of rural labour input in } \\
\text { agrarian activities }(100 \%-e)\end{array}$ & $70 \%$ & $41 \%$ \\
\hline $\begin{array}{l}\text { h. Share of rural agrarian labour } \\
\text { input in market-oriented } \\
\text { activities (see text) }\end{array}$ & $30-40 \%$ & $60-80 \%$ \\
\hline $\begin{array}{l}\text { i. Resulting share of total population } \\
\text { in market-oriented activities } \\
(\mathrm{d} \times \mathrm{g} \times \mathrm{h})\end{array}$ & $16-22 \%$ & $14-18 \%$ \\
\hline $\begin{array}{l}\text { Total share of labour input in } \\
\text { market-oriented activities }(\mathrm{c}+\mathrm{f}+\mathrm{i})\end{array}$ & $60-66 \%$ & $87-94 \%$ \\
\hline
\end{tabular}

Sources: see text.

Population density in 1514 has been based on an estimated area of 4,600 $\mathrm{km}^{2}$ (see Chapter 2, note 42).

\subsection{FLANDERS}

To all appearances, in Flanders a high level of market orientation had been reached much earlier than in Holland, owing to the county's early industrialisation and urbanisation. Towns first emerged in Flanders in the 10th century. Stimulated by the rise of the textile industry, a phenomenal urban growth took place in the 11th and particularly the 12th century. By 1200, Flanders had become the most urbanised region in 
northern Europe, with Ghent, Bruges and Ypres as its main centres of industry and trade. The three cities continued to grow in the 13th and, with the possible exception of Ypres, also in the first decades of the 14th century. In the latter half of that century, recurrent epidemics, warfare, and structural problems in the textile industry heralded decline. ${ }^{33}$

In contrast to Holland, Flanders had no medium-sized towns: besides the three large cities, there were only small and very small towns. The development of these lesser towns between the middle of the 14th and the late 15th century displays a differentiated pattern. Although many small towns-especially the older drapery centres but also, for instance, the small port towns in the Zwin estuarystagnated or declined in the 15th century, others developed favourably and expanded rapidly. The new industrial centre of Hondschoote is a good example, as are the ports of Ostend and Dunkirk. ${ }^{34}$

The earliest reliable demographic information for Flanders is provided by the Flanders Transport of 1469, an assessment of the demographic and economic conditions of the Flemish towns and rural districts made for taxation purposes. The Transport is not complete, but in combination with other sources it permits us to estimate the population numbers in all of Flanders in the third quarter of the 15th century. By then, about $35 \%$ of the Flemish population was living in towns. Around $47 \%$ of these townspeople lived in Ghent (about 60,000 residents) or Bruges (around 45,000). Another 40\% lived in one of the eighteen small towns with a population of 2,000 to 10,000; among them was Ypres, which by this time had seen its population fall to under the 10,000 mark. The remainder, about $13 \%$, lived in one of the many very small towns with fewer than 2,000 inhabitants. ${ }^{35}$ By 1500 , the urban ratio may actually have been somewhat lower than $35 \%$, if only because in the intermediate years Ghent and Bruges experienced a marked decline. ${ }^{36}$ This distribution of the urban

${ }^{33}$ Nicholas, Medieval Flanders, 29-38, 112-115, 117-119, 130-131, 273-275, 305-306.

${ }^{34}$ Stabel, Dwarfs among Giants, 34-43.

${ }_{35}$ Prevenier, 'Démographie'; for the towns slightly revised by Stabel, 'Demography and Hierarchy', 210-213. Here Stabel's figure for the urban population (just over 224,000) and Prevenier's for the countryside (just over 423,000) have been combined to calculate the urban ratio of $35 \%$.

${ }^{36}$ Stabel, Dwarfs among Giants, 31-33. Paul Klep has, in fact, suggested a very significant drop in the urban ratio in the late 15th and early 16th century (Klep, 'Population Estimates'), but his calculations are contested (cf. Stabel, Dwarfs among Giants, 19-20). 
population can be used to calculate the market orientation of the labour input of the urban population, using the same assumptions about agricultural activities in towns of varying sizes as in Holland. This results in a share of urban labour devoted to market-oriented activities of $92-97 \%$.

Information for the middle of the 14th century is much less reliable. Population estimates for Flanders before the late 15th century are fragmentary and uncertain. It is likely that the urban ratio in the 14 th century was higher than in the 15 th, but we do not know how much higher. Staying on the safe side, the urban ratio for the middle of the 14 th century has here been estimated at $40 \%{ }^{37}$ Total market orientation of urban labour input may also have been a little higher than in the late 15 th century, but the absence of demographic data precludes a translation into quantitative terms. In the calculations, levels of market orientation have therefore been kept at their late 15th-century level of 92-97\%.

The countryside of Flanders can be divided into two quite distinct regions. Inland Flanders, covering perhaps three quarters of the total area of the county, consists of sandy or loamy soils that were mainly occupied during the early or high Middle Ages. There were some large farms owned by lords in this densely populated region, but smallholding prevailed, and peasants retained secure property rights to their plots throughout the Middle Ages. The heavier soils of coastal Flanders were reclaimed later in time. The region was increasingly dominated by middle-sized and large farms, and by the end of the Middle Ages the great majority of these farms were held in leasehold. ${ }^{38}$ The degree of market orientation of agriculture in the two regions differed.

The predominant agrarian system in inland Flanders has been described as a 'commercial peasant system'. Peasants were primarily focused on feeding themselves and their families, putting in large amounts of labour to increase yields on their small plots; but as part of their survival strategy they also produced for the market. ${ }^{39}$ Because of the scale of the Flemish cities, their provisioning needs for both food and raw materials for the textile industry must have been relatively large. Therefore, by the middle of the 14th century

37 Stabel, Dwarfs among Giants, 19.

38 Soens and Thoen, 'Origins of Leasehold', 32-34.

39 Thoen, 'Twee gezichten, 76. 
the share of labour input in market-oriented activities was probably at the high end of the range of 30 to $40 \%$ estimated for Holland (and England).

However, market orientation of agriculture in inland Flanders most likely did not increase much in the late 14th and 15th century. Although Erik Thoen's detailed study of the agrarian economy in the inland Oudenaarde and Aalst districts demonstrates a rising share of industrial commodities such as rape seed, hops and particularly flax, a large part of the agricultural sector remained geared to subsistence. By the middle of the 16th century, peasants in the Oudenaarde district sowed at least half of their land with bread grains. There is good reason to believe they did not merely do this because of the high nutritional needs of flax and the crop rotation that had to be practised as a consequence, but also to satisfy the needs of their own families. Peasants owning less than two hectares cultivated bread grains on an even larger percentage of their plots than average (between 60 and $80 \%$ ), whether grain prices were high or not, suggesting that most of their grain crop was intended for auto-consumption. ${ }^{40}$ Larger farms no doubt produced for the market to a much greater extent, but the continued preponderance of small, mainly subsistence-oriented farms-in fact, the number of small farms probably grew in the 15th century ${ }^{41}-$ suggests that in inland Flanders the share of labour input in agriculture devoted to market-oriented activities underwent no significant changes between 1350 and 1500 .

In contrast to inland Flanders, agriculture in coastal Flanders experienced a transformation in the late Middle Ages. In the early 13th century, social structures in this newly reclaimed part of the county are reminiscent of the situation in Holland: the power of the count was strong, local lordship was relatively weak, and many peasants were freeholders. But whereas in Holland smallholding continued to exist until the end of the Middle Ages, in coastal Flanders leasehold gained ground from the 13th century onwards. This was accompanied by a process of land concentration: a minority of peasants accumulated substantial quantities of land at the expense of many others who lost their holdings. This process probably originated in the high costs of water management in the region, but it was accelerated by an

40 Thoen, Landbouwekonomie, 706-707, 722-726, 840-842.

${ }^{41}$ Ibid., 876. 
institutional factor rooted in customary law: the right of the count to expropriate land from landowners unable to pay their share in the expenses of dike maintenance or repair. ${ }^{42}$

The result was a predominance of middle-sized and large leasehold farms that mainly produced meat, dairy, and commercial crops. The Veurne district is a good example. In the early 16th century, the polders around Veurne were an important cattle-farming region. Although very little information on the marketing of meat and dairy produced on the large farms in this district is available, there can be no doubt that most of these products were sold on the urban markets in the vicinity. ${ }^{43}$ The polders also produced large quantities of wheat and barley. Wheat was used as bread grain for the farmer's family and the farm labourers, but the surplus was sold; the barley crop was almost entirely marketed. ${ }^{44}$ In short, while in the early 14 th century the market orientation of agrarian labour in coastal Flanders was probably not very different from the rest of the county, by the late 15 th century it must have been considerable higher. An estimate of 70 to $80 \%$ (the same as for English tenant farming $)^{45}$ seems realistic.

Urbanisation rates in coastal Flanders were probably similar to those in inland Flanders. An accurate figure cannot be given. Although late 15th-century population figures for towns and countryside are available per casselry, the five coastal casselries (the Franc of Bruges, Vier Ambachten, Veurne, Bergues and Bourbourg) all include parts of sandy inland Flanders as well as coastal polders. However since for these five casselries the urbanisation rate is 34\%-virtually the same as for Flanders as a whole-there is no reason to believe that in the coastal region a much smaller, or larger, percentage of the population lived in towns than in the rest of the county. ${ }^{46}$

However, differences existed in the proportion of rural labour devoted to non-agrarian activities. As we saw in Chapter 3, in the early 14th century, Flemish towns became more aware of rural competition and increasingly attempted to suppress rural cloth production.

42 Soens and Thoen, 'Origins of Leasehold', 43, 45, 47.

43 Vandewalle, Geschiedenis van de landbouw, 232.

${ }^{44}$ Ibid., 333-339.

${ }^{45}$ See below, section 9.4.

${ }^{46}$ The ratio of $34 \%$ has been calculated from the population in the towns in the five coastal casselries (collected from the list given by Stabel, 'Demography and Hierarchy', 210-211) and the rural population in these casselries (Prevenier, 'Démographie', 269). 
Spinning and other preparatory activities still took place in the countryside, but they were subordinated to the needs of urban industry. From the late 14th century, the countryside of inland Flanders increasingly turned to linen production as an alternative, combined with the cultivation of flax. Even though the development of the rural labour force towards greater occupational diversity and market orientation was probably muted by urban dominance, a modest growth did take place. Van Bavel's calculations show that in the rural districts around Aalst and Oudenaarde the share of labour input in textile production rose slightly in the course of the 14th and 15th centuries, from around $15 \%$ to around $20 \%$. Other proto-industrial activities did not acquire a prominent position. ${ }^{47}$ Of course, in Flanders too bakers, smiths and other artisans were active in the villages, selling their products to the local population. Assuming their numbers were similar to what they were in Holland, for inland Flanders the total share of rural labour input in non-agrarian activities can thus be estimated at about $20 \%$ in the early 14 th century and $30 \%$ around 1500 .

For coastal Flanders there is no similar detailed study, but the proportion of rural labour input devoted to non-agrarian activities appears to have moved in the opposite direction. In the early 14th century, many smallholding peasants in the coastal region combined agriculture with activities specific for the region, such as peat-digging, salt making, fishing, and dike maintenance. ${ }^{48}$ In this they much resembled the peasants in Holland. A share of labour input into non-agrarian activities of $30 \%$ seems realistic - the same as in Holland for the middle of the 14th century. By the early 16th century, however, the number of smallholders had dwindled. Consequently, the importance of nonagrarian labour in the countryside must have declined, from 30 to perhaps $20 \%$.

A calculation along the lines of what has been presented for Holland leads to the conclusion that at the end of the 15th century two-thirds to three-quarters of total labour input in inland Flanders was devoted to market-oriented activities. In the middle of the 14th century, this share had been only slightly lower (Table 8 ).

\footnotetext{
47 Van Bavel, 'Early Proto-Industrialization', 1116-1117, 1124-1125.

${ }^{48}$ Soens and Thoen, 'Origins of Leasehold', 41; cf. the reference to the declining importance of proto-industry in the schedule on page 33 of this article.
} 
Table 8 Share of labour input in market-oriented activities, Flanders

Mid 14th Late 15th / early 16th century century

Population 1469: c. 647,000

Density: c. 76 residents per $\mathrm{km}^{2}$

Urban sector

a. Urban population as percentage $\quad 40 \% \quad 35 \%$ of total (see text)

b. Share of urban labour input in market oriented activities (see text)

c. Resulting share of total population in market-oriented activities $(\mathrm{a} \times \mathrm{b})$

$92-97 \% \quad 92-97 \%$

$37-39 \% \quad 32-34 \%$

Rural sector

d. Rural population as percentage $\quad 60 \% \quad 65 \%$ of total $(100 \%-a)$

e. Share of rural labour input in non-agrarian activities (see text):

$\begin{array}{lll}\text { - Inland Flanders } & 20 \% & 30 \% \\ \text { - Coastal Flanders } & 30 \% & 20 \%\end{array}$

f. Resulting share of total population in market-oriented activities $(\mathrm{d} \times \mathrm{e})$ :
- Inland Flanders
$12 \% \quad 20 \%$
- Coastal Flanders
$18 \% \quad 13 \%$

g. Share of rural labour input in agrarian activities $(100 \%-\mathrm{e})$ :
- Inland Flanders
$80 \% \quad 70 \%$
- Coastal Flanders
$70 \% \quad 80 \%$

h. Share of rural agrarian labour input in market-oriented activities (see text):
- Inland Flanders
$30-40 \% \quad 30-40 \%$
- Coastal Flanders
$30-40 \% \quad 70-80 \%$

i. Resulting share of total population in market-oriented activities $(\mathrm{d} \times \mathrm{g} \times \mathrm{h})$ :
- Inland Flanders
$14-19 \% \quad 14-18 \%$
- Coastal Flanders
$13-17 \% \quad 36-42 \%$

Total share of labour input in market-

oriented activities $(\mathrm{c}+\mathrm{f}+\mathrm{i})$
- Inland Flanders
$63-70 \%$
$65-72 \%$
- Coastal Flanders
$67-74 \% \quad 82-89 \%$

Sources: see text.

Population density in 1469 has been based on an estimated area of $8,500 \mathrm{~km}^{2}$. This is the area of the current Belgian provinces of West-Vlaanderen and Oost-Vlaanderen plus Dutch Zeeuws Vlaanderen and the French Westhoek. 
The differences from Holland are clear: inland Flanders reached a higher level of market orientation at an earlier stage, but there was only very limited growth afterwards. In coastal Flanders, the share of labour input devoted to market-oriented activities in the middle of the 14th century would at best have been only marginally higher than in inland Flanders. However, at the end of the Middle Ages the highly commercialised nature of agriculture in coastal Flanders would have meant a total share of labour input in market-oriented activities of 82 to $89 \%-$ almost as high as in Holland. It should be stressed, though, that the lowlands of coastal Flanders covered perhaps a quarter of the total area of the county. Moreover, population densities in this region were much lower than in inland Flanders. ${ }^{49}$ For Flanders as a whole, market orientation would therefore have been considerably lower than the Holland figure.

\subsection{ENGLAND}

Demographic development in medieval England has been, and still is, the subject of scholarly debate: there is no general agreement on either the total population or the proportion living in towns before the middle of the 16th century. Towns in England emerged earlier than in Holland. Based on the references to urban land and houses in Domesday Book, by the late 11 th century some 8 to $10 \%$ of a population of 1 to 2 million may have been living in towns. In the 12th and 13th century, total population numbers soared. The more cautious estimates state that there may have been a little over 4 million people living in England at the end of the 13th century. ${ }^{50}$ The progress of urbanisation, however, seems to have been fairly modest; for the late 13th century, Campbell calculates an urban ratio of $15 \%$. Lonely at the top of the urban hierarchy stood London, estimated by Campbell at 60,000 inhabitants, followed at a considerable distance by York $(22,700)$. Of all townspeople,

${ }^{49}$ For the casselry of Veurne, densities for the inland (sandy) and the coastal (polder) part have been calculated by Vandewalle, Geschiedenis van de landbouw, 56-57.

${ }^{50}$ Much of the discussion on demographic development in the 12th, 13th and early 14 th century is related to problems with interpreting Domesday Book information. For a survey, see Britnell, 'Commercialisation and Economic Development', 9-12. For a recent addition proposing a two-phased model of growth, cf. Langdon and Masschaele, 'Commercial Activity', esp. 54-68. 
$15 \%$ lived in one of these two large cities. In contrast to Flanders, England had medium-sized towns of 10,000 to 20,000 inhabitants, but they were few. Only Bristol, Lincoln and Norwich qualified as such; together they were home to $6 \%$ of the urban population. Another $39 \%$ lived in towns with between 2,000 and 10,000 inhabitants and the remaining $40 \%$ in towns with less than 2,000 inhabitants. ${ }^{51}$

An earlier, less detailed estimate by Dyer arrives at a somewhat higher urban ratio of $20 \%$ for the year 1377 . The main reason for the difference appears to be Dyer's much higher estimate of the average size of the smallest towns (the towns with less than 2,000 inhabitants): 750 residents instead of the 340 used in Campbell's calculations. Dyer's higher urban ratio thus assumes an even higher proportion of the urban population living in the smallest towns than the $40 \%$ calculated by Campbell..$^{52}$ Here Campbell's urban ratio of $15 \%$ has been taken as a minimum and Dyer's $20 \%$ as a maximum for the middle of the 14th century. Assuming that in England-just as in Flanders and Holland $-50 \%$ of urban agricultural labour was devoted to production for the market, the total share of urban labour input into market-oriented activities can be estimated at 89 to $94 \%$.

The Black Death took the lives of perhaps half the population of England. Recovery did not begin until the early 16th century, and only in the 17 th or even the 18 th century did the population figure once more reach the level of around the year $1300 .{ }^{53}$ Whether in the late 14 th and 15th century towns fared better or worse than the countryside is not quite clear. Recent research, based on a comparison of the returns for 100 provincial towns in the poll tax of 1377 and the lay subsidy of $1524 / 25$, suggests that the urban ratio stabilised or may even have declined a little. The calculations below are based on the first of these two options. ${ }^{54}$ The development of the market orientation of urban labour input is also open to debate. There may have been more room for agricultural activities in and around the shrunken towns; however, raised standards of living may also have stimulated

${ }^{51}$ Campbell, 'Benchmarking Medieval Economic Development', 11-18, 36.

52 Dyer, 'How Urbanized was Medieval England?', 174-176; Dyer, 'Small Towns', 506,510 .

${ }_{53}$ Hatcher, Plague, 55-63.

${ }^{54}$ Rigby, 'Urban Population'. Rigby's article contains well-founded criticism of the work of Alan Dyer, who on the basis of the same data claims a modest rise of the urban ratio. 
market demand. Assuming the two trends more or less kept each other in balance, the market orientation of urban labour is taken to have stabilised from the 14th century.

In the countryside, estate surveys for the 12th century testify to the presence of other than strictly agrarian activities: they mention large numbers of millers, smiths, and carpenters and also contain occasional references to other professions such as masons and weavers. Most of these people probably also worked their land; some of them seem to have held that land as a 'service holding', rendering their specialised services to the lord of the manor in return. They can therefore not be considered as purely market-oriented producers. Still, in the course of the 13th century the number of specialised craftsmen in the villages increased and the system of service holdings almost entirely disappeared, giving way to monetary rents. ${ }^{55}$ Some regional specialisation emerged: growing urban demand gave rise to activities such as mining, charcoal burning, pottery, tile-making, commercial sea-fishing, and salt production, depending on local resources. ${ }^{56}$

These activities were restricted to specific, often small, regions; moreover, villagers usually combined them with agriculture. Therefore, probably only a modest part of the labour force was involved in them. On the other hand, there is no reason to believe the proportion of the English rural population engaged in providing basic services to their neighbours was much smaller than the rates assumed for Holland or Flanders. As demonstrated in Chapter 3, to give just one example, many women occasionally sold bread and beer to other villagers, in England as well as in Holland. The issue can also be approached from another angle: the fact that about $40 \%$ of the peasantry did not have enough land to support a family must have induced people to look for ways to supplement their income ${ }^{57}$ Harvest time excepted, the agricultural sector could accommodate only limited numbers of wage labourers, so non-agricultural activities provided an alternative. In short, Britnell's assumption that in total about $5 \%$ of rural labour input would have been devoted to non-agrarian activities seems an underestimation..$^{58} \mathrm{~A}$ rate of 10 to $20 \%$ sits more comfortably with the evidence for the Low Countries.

\footnotetext{
55 Harvey, 'Non-Agrarian Activities', 107-111.

56 Britnell, Commercialisation, 113-114.

57 Dyer, 'Were Peasants Self-Sufficient?', 655.

58 Britnell, Commercialisation, 115.
} 
This takes us to the agrarian sector of the rural economy. In the late 13 th and early 14th century, seignorial agriculture balanced between the needs of consumption and the attractions of the market. There were large differences depending on product, location, and the needs of the lord's household. In the London region, lay lords tended to sell a large part of their demesnes' grain harvest, whereas convents and colleges often transferred a considerable share to the central household in town. Nevertheless, for the London region as a whole, an estimated $50 \%$ of the grain crop (after deduction of next year's seed) ended up in the market. ${ }^{59}$ In more distant regions, demesne grain cultivation was probably less commercialised, but the products of pastoral farming were frequently marketed. Peterborough Abbey, its manors scattered over the east Midlands, sold only a very small part of its grain crop but about half the yield of the dairy herds and almost all of the wool from its sheep. ${ }^{60}$

The seignorial sector probably covered between one fifth and one third of the land under cultivation and produced a more or less corresponding part of agricultural output. Peasants, either villeiners or freeholders, were responsible for the remainder. ${ }^{61}$ The yardlanders, the most prosperous $25 \%$ or so of the peasantry, probably followed strategies very similar to those adopted by manorial lords: they were influenced by market opportunities, but also by the subsistence needs of their own families and those of the village community that regulated land use on the open fields. An analysis of the lay subsidy roll of 1297 for 44 villages in Bedfordshire has shown that the taxable wealth of the top layer of the peasantry in these villages was to a large extent determined by the distance to the nearest weekly market. ${ }^{62}$ The correlation is particularly strong for wealth held in sheep, followed by the malting grains oats and dredge (a mixture of barley and oats), and by other livestock. For wheat, however, no correlation appears in the analysis, suggesting that the decision to cultivate bread grains depended on considerations of subsistence rather than on the market.

Yardlanders, at least in normal years, had a surplus to sell: according to Dyer's budget calculations, they were able to market up to half of their grain crops and an even higher share of products like meat, dairy,

\footnotetext{
59 Campbell et al., Medieval Capital, 74-75, 176.

60 Biddick, Other Economy, 72-73, 95, 109-110.

61 Campbell, English Seigniorial Agriculture, 56-60.

${ }^{62}$ Biddick, 'Medieval English Peasants', 828.
} 
eggs, fruit, and vegetables.$^{63}$ It is doubtful whether the agricultural activities of those with more modest holdings were as much marketoriented as this, let alone those of the $40 \%$ of rural households with so little land that it could not sustain a family. Even this latter category may well have had a cow out on the common pasture and sold part of the dairy it produced - to give just one example of a market-oriented strategy. However, considering the fact that people who owned but little land already depended on wage labour for part of their sustenance, they would probably have preferred to use most of what their tiny plots did render to reduce their dependency on the market and increase selfsufficiency. In total, perhaps 40 to $50 \%$ of labour input in the seignorial sector and 30 to $40 \%$ in peasant agriculture may have been devoted to market-oriented production.

Between the early 14th and the late 15th century, important changes in the English rural economy took place. A higher standard of living gave rise to an increased demand for industrial products, stimulating further regional specialisation. ${ }^{64}$ Consequently, the proportion of rural labour input into non-agrarian activities was no doubt higher in 1500 than it had been in 1300 or 1350 . Court roll evidence suggests that in early 16th-century rural Norfolk just over a quarter of the rural population found primary employment in crafts and services. ${ }^{65}$ Norfolk belonged to the most commercialised part of England; proportions were probably lower elsewhere. On the other hand, many peasants and agricultural labourers may have combined agricultural work with part-time industrial activities-at the end of the Middle Ages this combination was quite common. ${ }^{66}$ An increase of the share of rural labour input into non-agrarian activities to 20 to $30 \%$ therefore seems reasonable.

Agriculture also experienced changes. Direct management of demesnes declined strongly. Rising labour costs and declining prices eroded profits; in growing numbers lords decided they were better off as lessors than as managers. Between 1300 and 1400 the seignorial sector may already have been reduced by half, and it continued to

63 Deduced from the calculations made by Dyer, Standards of Living, 112-114. For the size of landholdings, Ibid., 119. Cf. Dyer, 'Were Peasants Self-Sufficient?', $656-660$.

64 Britnell, Commercialisation, 195-196.

65 Whittle, Agrarian Capitalism, 236.

66 Dyer, Standards of Living, 145-146. 
contract in the 15 th century. ${ }^{67}$ The former demesne lands-perhaps a fifth or a quarter of all agricultural land-were leased out to an emerging class of tenant farmers, many of them of peasant origin. Relationships between lords and tenants changed, and new methods of production and management were introduced: the lessees practised a large-scale, capital-intensive, specialised, and highly commercialised type of agriculture. ${ }^{68}$ For this group, a share of 70 to $80 \%$ of labour input into cultivating marketable crops does not seem too high.

Changes in peasant agriculture were not as dramatic. As population numbers diminished, many peasants were able to acquire land that fell vacant, thus enlarging their holdings. Some fields were converted into pasture and more peasants than before owned livestock. This gave them a better chance of producing a marketable surplus than their predecessors. On the other hand, just like manorial lords, peasants were confronted with slack markets and falling prices. ${ }^{69}$ In the end, most yardlanders and half-yardlanders continued to practise mixed farming with a strong emphasis on grain cultivation, balancing between the needs of their own families and marketing opportunities. ${ }^{70}$ Ultimately, the proportion of labour input in market-oriented production in the peasant sector was probably not very different from the 30 to $40 \%$ reached in the early 14 th century.

These estimates combined (see Table 9) suggest an increase in the share of labour input in market-oriented activities from 46 to $62 \%$ in the early 14 th century to 57 to $71 \%$ by 1500 - a considerable increase, but not on a par with developments in Holland.

Of course regional differences were substantial. In the most commercialised eastern part of England, market orientation at the end of the Middle Ages was certainly at the top end of the ranges indicated for the country as a whole and may even have been a little above it, as a look at the county of Suffolk may demonstrate. ${ }^{71}$ Landownership and social structure in Suffolk, one of the most densely populated counties of England, exhibited some special features. Manors were small in comparison to other parts of England, and most manorial

${ }^{67}$ Campbell, English Seigniorial Agriculture, 59-60.

${ }^{68}$ Dyer, Making a Living, 346-349.

${ }^{69}$ Dyer, Standards of Living, 141-144, 148-149.

70 Dyer, Making a Living, 353.

${ }^{71}$ The following is based on Bailey, Medieval Suffolk, 21-27 (seignorial agriculture), 39-41 (peasant agriculture), 103-104 (communal regulations of land use), 129 (nonagrarian activities), and 153 (urbanisation). 
Table 9 Share of labour input in market-oriented activities, England

\begin{tabular}{|c|c|c|}
\hline & Early 14 th century & $\begin{array}{l}\text { Late } 15 \text { th / early } \\
16 \text { th century }\end{array}$ \\
\hline & $\begin{array}{l}\text { Population 1290: } \\
4.0 \text { million? } \\
\text { Density: } 31 \text { residents } \\
\text { per } \mathrm{km}^{2}\end{array}$ & $\begin{array}{l}\text { Population 1541: } \\
2.8 \text { million } \\
\text { Density: } 21 \\
\text { residents per } \mathrm{km}^{2}\end{array}$ \\
\hline \multicolumn{3}{|l|}{ Urban sector } \\
\hline $\begin{array}{l}\text { a. Urban population as percentage of } \\
\text { total (see text) }\end{array}$ & $15-20 \%$ & $15-20 \%$ \\
\hline $\begin{array}{l}\text { b. Share of urban labour input in } \\
\text { market-oriented activities (see text) }\end{array}$ & $88-94 \%$ & $89-94 \%$ \\
\hline $\begin{array}{l}\text { c. Resulting share of total population in } \\
\text { market-oriented activities }(\mathrm{a} \times \mathrm{b})\end{array}$ & $13-19 \%$ & $13-19 \%$ \\
\hline \multicolumn{3}{|l|}{ Rural sector } \\
\hline $\begin{array}{l}\text { d. Rural population as percentage of total } \\
(100 \%-a)\end{array}$ & $80-85 \%$ & $80-85 \%$ \\
\hline $\begin{array}{l}\text { e. Share of rural labour input in non- } \\
\text { agrarian activities (see text) }\end{array}$ & $10-20 \%$ & $20-30 \%$ \\
\hline $\begin{array}{l}\text { f. Resulting share of total population in } \\
\text { market-oriented activities }(\mathrm{d} \times \mathrm{e})\end{array}$ & $8-17 \%$ & $16-26 \%$ \\
\hline $\begin{array}{l}\text { g. Share of rural labour input in agrarian } \\
\text { activities }(100 \%-e)\end{array}$ & $80-90 \%$ & $70-80 \%$ \\
\hline \multicolumn{3}{|l|}{$\begin{array}{l}\text { h. Share of rural agrarian labour input in } \\
\text { market-oriented activities (see text): }\end{array}$} \\
\hline - seignorial sector & $40-50 \%$ & $20-25 \%$ \\
\hline $\begin{array}{l}\text { - farmer tenants } \\
\text { - peasants }\end{array}$ & & $70-80 \%$ \\
\hline - peasants & $30-40 \%$ & $30-40 \%$ \\
\hline \multicolumn{3}{|l|}{$\begin{array}{l}\text { i. Resulting share of total population in } \\
\text { market-oriented activities }(d \times g \times h) \text { : }\end{array}$} \\
\hline - seignorial sector & $5-11 \%$ & $1-2 \%$ \\
\hline - farmer tenants & & $8-14 \%$ \\
\hline - peasants & $13-24 \%$ & $12-20 \%$ \\
\hline $\begin{array}{l}\text { Total share of labour input in market- } \\
\text { oriented activities }(c+f+i)\end{array}$ & $46-62 \%$ & $57-71 \%$ \\
\hline
\end{tabular}

Sources: see text.

The estimated population in 1541 is given by Wrigley and Schofield, Population History, 208. The division of labour input in the agriculture over the seignorial sector, farmer tenants, and peasants is estimated at $20-30 \%: 0 \%: 80-70 \%$ in the early 14 th century, and at $5 \%: 20-25 \%: 75-70 \%$ by 1500 . Because of interdependencies between the components, the ranges indicated in the last line are narrower than summation of the lowest and highest estimates for each of the components suggests (e.g. the share of non-agrarian and agrarian rural activities cannot both be at the high end of the indicated ranges at the same time). 
lords exercised only limited powers. About $80 \%$ of the peasants were freemen. Smallholding prevailed: in the early 14 th century about three quarters of all peasants, a higher share than in most other counties, had less than 10 acres of land. Communal land use arrangements were mostly restricted to pasturing rights, and individuals could usually crop their lands as they saw fit.

Let us first take a look at the situation in the early 14th century. Manorial accounts suggest that, in Suffolk, commercialisation of the seignorial sector was at the high end of the scale indicated in Table 9. This is probably also true for the peasant sector. As elsewhere, those who held no more than a few acres probably gave priority to feeding their families, but middling and wealthy peasants were highly responsive to market forces. In the sources, they are found selling grain, renting gardens and orchards, producing hemp, and leasing the lord's dairy herds.

Considering the fact that most holdings were too small to sustain a family, it is hardly surprising that many peasants supplemented their income with activities like sea-fishing, brewing, or petty retailing. The share of rural labour input in non-agrarian activities was therefore probably also at the high end of the range given for England as a whole. Nevertheless, urbanisation levels appear to have been moderate: despite the large number of small towns, the urbanisation rate in the early 14 th century was only about $15 \%$. A calculation based on these assumptions arrives at an estimate of, at most, $60 \%$ of total labour input devoted to market-oriented activities.

Between the early 14 th and the early 16 th century population numbers in Suffolk fell sharply, just as they did elsewhere in England; but despite demographic contraction, the Suffolk economy did remarkably well. ${ }^{72}$ The rise of tenant farming and the yeomanry was not very different from developments elsewhere in England; but responding to a rising demand for meat and dairy from the much larger group of people that could now afford these products, Suffolk experienced a very pronounced shift to cattle farming. By the end of the 15th century, cattle farming dominated the rural economy. This probably allowed agriculture to maintain its commercial orientation on the relatively high early 14th-century level.

72 The following is based on Bailey, Medieval Suffolk, 153 (population numbers), 213-226 (pastoral farming), 269-278 (industries), 245 and 288 (combination industrial work and smallholding), 279-286 (urbanisation). 
Even more striking was the rapid rise of industries such as brickmaking, leather working, and particularly textile productionlikewise in response to raised living standards. Spreading from the older urban centres to small towns and villages, the textile sector offered employment to an increasing share of the rural population of Suffolk. According to Bailey, by 1500 about one-third of the rural population earned a living predominantly from crafts. ${ }^{73}$ Certainly, many combined this with agricultural work, holding on to their few acres of land to provide the household with some basic foodstuffs; on the other hand, many peasants and agricultural labourers probably also found part-time employment in the cloth industry. It is therefore safe to assume that the total share of rural labour input into non-agrarian activities was above the range indicated in Table 9 for England as a whole: 30 to $40 \%$ (instead of 20 to $30 \%$ ) seems reasonable.

The rise of the textile industry also affected urbanisation. In contrast to the general trend in England, the urban ratio in Suffolk increased markedly at the end of the Middle Ages-by the early 16th century, about $30 \%$ of the Suffolk population lived in towns. A calculation that takes both the raised estimates for the share of non-agrarian activities and the urban ratio into account, would suggest that by 1500 a total share of, at most, $77 \%$ of labour input in Suffolk was devoted to market-oriented activities.

\subsection{Conclusions}

The aim of Chapters 8 and 9 has been to test market performance in late medieval Holland by looking at two quantitative indicators: market integration in Chapter 8 and market orientation in the current chapter. As we have seen, Holland's advance over England and Flanders on the issue of market integration was limited. In contrast, the results for market orientation as presented in the current chapter suggest some striking differences. Admittedly, these results should be seen as indications. They are composed from estimates of the share of labour input devoted to market-oriented activities; some of these estimates are rooted in detailed research, others necessarily rest on much less solid ground. Even so, the trend in Table 10, which summarises the results, is clear.

\footnotetext{
${ }^{73}$ Ibid., 294.
} 
Table 10 Share of labour input in market-oriented activities: Holland, Flanders, and England

\begin{tabular}{lll}
\hline & $\begin{array}{l}\text { Early / mid 14th } \\
\text { century }\end{array}$ & $\begin{array}{l}\text { Late 15th / early 16th } \\
\text { century }\end{array}$ \\
\hline $\begin{array}{l}\text { Holland } \\
\text { Flanders }\end{array}$ & $60-66 \%$ & $87-94 \%$ \\
- Inland Flanders & $63-70 \%$ & $65-72 \%$ \\
- Coastal Flanders & $67-74 \%$ & $82-89 \%$ \\
$\begin{array}{l}\text { England: } \\
\text { - Range for England as a whole }\end{array}$ & $46-62 \%$ & $57-71 \%$ \\
- Suffolk (maximum figures) & $60 \%$ & $77 \%$ \\
\hline
\end{tabular}

In Flanders a considerable level of commercialisation had been reached by 1350 . After this, market orientation rose markedly in the coastal area; but as virtually no progress was made in larger and more densely populated inland Flanders, for the county as a whole the increase of market orientation must have been limited. In early 14th-century England, market orientation was relatively low. In the next century and a half, commercialisation did increase, but even in the most commercialised eastern part of the country it did not reach the same level as in Holland. Here, in the middle of the 14th century, commercialisation was below the Flemish level, but by the early 16th century an impressive $90 \%$ or so of labour input was devoted to market-oriented activities. This high figure resulted from three interrelated elements: a high urban ratio, the widespread presence of non-agrarian activities in the Holland countryside, and-despite the predominance of small family farms-the highly commercialised nature of agriculture.

These three elements are constituents of a commercialised economy rather than explanations for its rise. For that we need to look deeper, following the suggestions made in the previous chapter. Non-institutional factors were no doubt important. For example, rising standards of living triggered changes in consumption patterns. Common people in the post-Plague era could spend more on food, drink, and clothing than their predecessors, thus stimulating market-oriented pastoral farming and encouraging the growth of urban industries. This happened in Holland; it also happened in coastal Flanders (at least with regard to cattle farming) and in Suffolk, and for that matter also in other parts of Europe. A second non-institutional factor affected Holland alone. Because of the subsidence of the peat soil, bread grain cultivation in Holland became increasingly problematic from the late 
14th or early 15th century onwards. Peasants adapted en masse to the new situation by shifting to pastoral farming and other forms of market-oriented agriculture, by taking up proto-industrial activities in the countryside or-very frequently-by a combination of both.

However adaptation was not automatic. Severe flooding and repeated harvest failure, especially since they were preceded by recurrent outbursts of the Plague in the second half of the 14th century, might have been disastrous: they could well have led to serious decline and depopulation. This did not happen; on the contrary, population numbers recovered with remarkable speed from the impact of the Plague. Holland's society was apparently sufficiently robust to cope with such adverse circumstances.

The explanation for this resilience can only be found in institutional factors, in turn related to the structure of society. Among these factors are the favourable commodity market institutions discussed in the first two parts of this book. That institutions did indeed matter is also suggested by the case of Suffolk. Although Suffolk, in contrast to Holland, experienced a sharp demographic decline during the late Middle Ages, at the same time commercialisation increased more rapidly than in most other English counties. One of the factors-not the only onethat contributed to Suffolk's relative success was the way in which social structures encouraged entrepreneurship and trade. ${ }^{74}$ In fact, in some respects-such as the weak character of manorialism, the weakness of communal restrictions on land use, and the presence of many small towns that did not impose strict controls on trade and industry-Suffolk institutions are reminiscent of Holland rules and practices.

Returning to Holland, we can conclude that the strong growth of market orientation between 1350 and 1500 would not have been possible without the support of an efficient organisation of commodity markets. Holland's favourable institutions did not generate high levels of commercialisation of their own accord: the process was ultimately triggered by non-institutional forces. But the contribution of the institutional framework was nonetheless essential: it facilitated and supported flexible adaptation to changing circumstances.

${ }^{74}$ Bailey, Medieval Suffolk, 145, 290-293. 